\title{
Koronavirüs Anksiyete Envanteri (KAE): Türkçeye Uyarlama, Geçerlik ve Güvenirlik Çalışması
}

\section{Coronavirus Anxiety Inventory's (CAI) Turkish Adaptation: Testing its Validity and Reliability}

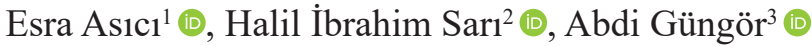

'Dr. Öğr. Üyesi, Kilis 7 Aralık Üniversitesi, MREF Eğitim Fakültesi, Kilis, Türkiye

${ }^{2}$ Doç. Dr., Kilis 7 Aralık Üniversitesi, MREF Eğitim Fakültesi, Kilis, Türkiye

${ }^{3}$ Dr. Öğr. Üyesi, Düzce Üniversitesi, Eğitim Fakültesi, Düzce, Türkiye

ORCID: E.A 0000-0003-0872-9042;

H. I. S. 0000-0001-7506-9000;

A. G. 0000-0002-7945-0906

Sorumlu yazar/Corresponding author:

Esra Asıcl,

Kilis 7 Aralık Üniversitesi, MREF Eğitim

Fakültesi, Eğitim Bilimleri Bölümü, KilisTürkiye

E-posta/E-mail: esraasici01@gmail.com

Başvuru/Submitted: 13.01.2021 Revizyon Talebi/Revision Requested: 04.03.2021

Son Revizyon/Last Revision Received: 14.03.2021

Kabul/Accepted: 15.03.2021

Online Yayın/Published Online: 26.07.2021

Citation/Atıf: Asıcı, E., Sarı, H. İ., Güngör, A. (2021). Koronavirüs Anksiyete Envanteri (KAE): Türkçeye Uyarlama, Geçerlik ve Güvenirlik Çalışması. Psikoloji Çalışmaları Studies in Psychology, 41 (2), 711-734. https://doi.org/10.26650/SP2021-860079
ÖZ

Koronavirüs (COVID-19) pandemisinin kontrol edilmesi ve pandemiyle ilişkili psikolojik sorunların önlenmesi açısından, pandemiye karşı gösterilen psikolojik tepkileri anlamak önemlidir. $\mathrm{Bu}$ araştırma pandemi sürecinde gözlenen psikolojik tepkilerden biri olan anksiyeteye odaklanmıştır. Araştırmanın amacı, Koronavirüs Anksiyete Envanteri'ni (Wheaton, Ward, Sanders, Reel ve van Meter, 2020) Türkçeye uyarlamak ve ölçeğin geçerliğini ve güvenirliğini test etmektir. Araştırmaya yaşları 18 ile 32 arasında değişen, 335 kadın, 93 erkek olmak üzere toplam 428 lisans öğrencisi katılmıştır. Verilerin analizinde Mplus ve R istatistik paket programları kullanılmıştır. Türkçe ölçek formunun yapı geçerliği doğrulayıcı faktör analizi aracılığıyla test edilmiştir. Ayrıca, Koronavirüs Anksiyete Envanteri ile Depresyon, Anksiyete ve Stres Ölçeği arasındaki ilişkiler korelasyon analiziyle incelenmiştir. Güvenirlik çalışmaları kapsamında Cronbach alfa iç tutarlılık katsayısı hesaplanmıştır. Doğrulayıcı faktör analizi sonucunda, Koronavirüs Anksiyete Envanteri'nin dokuz maddeden oluşan tek faktörlü yapısının yeterli uyum değerlerine sahip olduğu belirlenmiştir. Bir diğer deyişle, ölçeğin tek faktörlü yapısı koronavirüsle ilgili anksiyeteyi değerlendirme açısından iyi yapısal özelliklere sahiptir. Madde faktör yük değerleri .56 ile .81 arasında değişmiştir. Cronbach alfa iç tutarlılık katsayısı .84 olarak hesaplanmıştır. Alt ve üst \%27'lik grupların ölçekten aldıkları puanlar arasındaki farkın istatistiksel olarak anlamlı olduğu saptanmıștır. Ayrıca, Koronavirüs Anksiyete Envanteri ile depresyon, anksiyete ve stres arasında istatistiksel olarak anlamlı düzeyde pozitif yönde ilişkiler olduğu belirlenmiştir. Sonuç olarak, araştırmada Koronavirüs Anksiyete Envanteri'nin 7'li Likert tipine dayanan dokuz maddelik Türkçe versiyonunun üniversite öğrencilerinin koronavirüsle ilgili yaşadığı anksiyeteyi değerlendirmede kullanılabilecek geçerli ve güvenilir bir ölçme aracı olduğuna ilişkin kanıtlar elde edilmiştir. Bu araştırmada, Koronavirüs Anksiyete Envanteri pandemi sürecinde üniversite ögrencilerinin anksiyete düzeyini belirlemek amacıyla kullanılmıştır. Gelecek çalışmaların, envanteri farklı yaş gruplarında ve cinsiyete göre daha dengeli bir katılımc1 grubunda kullanması faydalı olabilir.

Anahtar Kelimeler: COVID-19, Koronavirüs anksiyete envanteri, pandemi, anksiyete, ölçek uyarlama 


\section{ABSTRACT}

Understanding people's psychological reactions to the pandemic is important in controlling the spread of disease and preventing psychological disorders associated with the COVID-19 pandemic. This study focuses on anxiety as a psychological reaction to the coronavirus pandemic. It aims to produce a Turkish adaptation of the Coronavirus Anxiety Inventory (CAI; Wheaton, Ward, Sanders, Reel, \& van Meter, 2020) and examine its reliability and validity. The study participants consisted of 428 undergraduate students (335 females and 93 males) aged between 18 and 32 years. The researchers used Mplus and R programs for data analysis and confirmatory factor analysis to test the construct validity of the Turkish adaptation. Moreover, using correlation analysis, the researchers examined the relationship between CAI and Depression Anxiety Stress Scale (DASS-21). Cronbach's alpha internal consistency coefficient was calculated to test the reliability of the scale. The results of the confirmatory factor analysis showed that the single-factor structure of the CAI with nine items had adequate fit indices, that is, it showed good features in terms of measuring coronavirus-related anxiety. Item factor loadings changed between 0.56 and 0.81 , and Cronbach's alpha internal consistency coefficient was 0.84. A statistically significant difference was found between the scores of the upper and lower $27 \%$ groups. Furthermore, statistically significant positive relationships between CAI and DASS were noted. Consequently, this study provides a number of evidences that the Turkish adaptation of CAI with nine items based on a seven-point Likert-type scale was a reliable and valid instrument for measuring coronavirus-related anxiety in undergraduate students. This research uses CAI to determine university students' anxiety levels amid the COVID-19 pandemic. The researchers suggest that particular attention should be given to a balanced distribution in terms of gender and age in future studies.

Keywords: COVID-19, Coronavirus Anxiety Inventory, pandemic, anxiety, scale adaptation

\section{EXTENDED ABSTRACT}

Numerous pandemics, such as the Spanish flu, Asian flu, Hong Kong flu, and swine flu, have occurred through human history. The coronavirus first appeared in Wuhan Province in China, and the World Health Organization declared COVID-19 as a global pandemic on March 11, 2020. By March 5, 2021, more than 115 million people were diagnosed with coronavirus, and more than 2 million people died due to coronavirus worldwide (WHO, 2021). The coronavirus pandemic affected other countries worldwide, including Turkey.

Although governments implement several measures to prevent the spread of disease during pandemics, one of the most crucial factors is individual reactions to a pandemic (Bish \& Michie, 2010). Various psychological factors affect such individual reactions. Investigating these factors is vital in terms of prevention and intervention because they have important roles in successfully controlling pandemics. One of these psychological factors is anxiety. It motivates people to exhibit protective behaviors and, at an excessive level, may trigger the development of psychological problems (Taylor, 2019; Wheaton et al., 2012). Therefore, measuring anxiety levels during a pandemic is valuable. Hence, this study aims to adapt the Coronavirus Anxiety Inventory (CAl; Wheaton, Ward, Sanders, Reel, \& van Meter, 2020) into Turkish and examine its reliability and validity. 


\section{Method}

This study was conducted with two different participant groups. In the pilot study, participants included 350 undergraduate students (264 females and 86 males), whereas in the final study, participants included 428 undergraduate students (335 females and 93 males). A demographic information form, CAI, and Depression Anxiety Stress Scale (DASS21; Yıldırım, Boysan, \& Kefeli, 2018) were used to collect data. Furthermore, to analyze data, the researchers used confirmatory factor analysis (CFA), item analysis, Cronbach's alpha internal consistency coefficient, and correlation analysis.

\section{Results}

The pilot study was conducted for the version of CAI that comprised 10 items based on five-point Likert-type scale. The results showed that CAI had low item loads, corrected item-total correlations, and Cronbach's alpha values, in addition single-factor structure was unconfirmed. Therefore, a final study was performed for the version of CAl that comprised 10 items based on seven-point Likert-type scale.

In the final study, all corrected item-total correlations showed to be higher than 0.40 , except for the ninth item; hence, the researchers excluded it from the analysis. The Cronbach's alpha internal consistency coefficient was 0.84 for nine items. The results of the first CFA showed that the single-factor structure with nine items have inadequate fit indices. Thus, based on the modification indices, the error variances of items two and five as well as items three and four were linked. The results of the last CFA $\left(X^{2} / d f=2.90, \mathrm{RMSEA}=0.06, \mathrm{CFI}=\right.$ $0.98, \mathrm{TLI}=0.97, \mathrm{WRMR}=0.55)$ revealed adequate fit indices (Bentler, 1980; Browne \& Cudeck, 1993; Kline, 2011, Marsh et al., 2006; Yu, 2002). The item loads ranged from 0.56 to 0.81 . The results of zero-order correlations showed that CAI scores were statistically significant and positively associated with depression $(r(426)=0.34, p<0.01)$, anxiety $(r(426)=0.38, p<0.01)$ and stress $(r(426)=0.45, p<0.01)$.

\section{Discussion}

This study provides several evidences that the Turkish adaptation of CAl comprising nine items based on a seven-point Likert-type scale ( $1=$ none; $7=$ very much) is a reliable and valid instrument for measuring coronavirus-related anxiety in undergraduate students. Numerous studies have been conducted abroad on reactions toward pandemics and the psychological factors underlying these reactions (Bish \& Michie, 2010; Karademas et al., 2013; Moussaoui, Ofosu \& Desrichard, 2020; Oosterhoff \& Palmer, 2020; Pasion, Paiva, Fernandes, \& Barbosa, 2020; Rubaltelli et al., 2020; Wang et al., 2020; Wise et al., 2020; Vally, 2020); however, similar 
studies conducted in Turkey are scarce (e.g. Ceviz et al., 2020; Kuru \& Uymaz, 2020). Hence, researchers may use CAI to examine the relationship between university students' level of coronavirus-related anxiety and their reactions toward the pandemic. Additionally, such a tool may be used to determine university students who have high levels of coronavirusrelated anxiety and those do not feel any anxiety, and interventions may be designed for the needs of these students. In future studies, the inclusion of different groups, such as health workers, adults, or parents, may prove beneficial.

In this study, item nine (To what extent has the threat of Coronavirus influenced your travel plans?) had an insufficient corrected item-total correlation value. Hence, the researchers excluded it from the analysis. COVID-19 pandemic in Turkey started in March 2020 and reached its first peak in April 2020; however, higher education continued during these months. Thus, university students may not have travel plans during these months. The low corrected item-total correlation value for item nine may be related to the participants' lack of travel plans. On another note, this result may be a result of lockdown practices. Future studies may retest whether item nine works at different times and in different sample groups. 
Pandemi, insanların bağışıklığının düşük düzeyde olduğu bir hastalığın bulaşıcılık özelliği sayesinde geniş bir coğrafi bölgeye yayılması ve çok sayıda insanı etkilemesi durumudur(Qui, Rutherford, Mao ve Chu, 2016/2017). İnsanlık tarihi boyunca dünyada İspanyol gribi (1918-1920), Asya gribi (1957-1958), Hong Kong gribi (1968-1970) ve domuz gribi (2009-2010) gibi pek çok pandemi görülmüştür (Saunders-Hastings ve Krewski, 2016). Çin'in Wuhan eyaletinde 2019 yılının Aralık ayında ortaya çıkan koronavirüsün 11 Mart 2020 tarihinde Dünya Sağlık Örgütü tarafından küresel pandemi olarak ilan edilmesiyle, dünya pandemi tarihine bir yenisi daha eklenmiştir. Dünya Sağlik Örgütü'nün 5 Mart 2021 tarihinde yayınladığı verilere göre, dünya genelinde 115 milyondan fazla kişi koronavirüs tanısı almış ve iki milyondan fazla kişi koronavirüs nedeniyle hayatını kaybetmiştir (WHO; Dünya Sağlık Örgütü, 2021). Koronavirüsün küresel pandemi ilan edildiği 11 Mart 2020 tarihinde Türkiye'de de ilk vaka görülmüş ve ilk vakanın görülmesinin ardından vaka sayılarında hızlı bir artış olmuştur. Türkiye'de 5 Mart 2021 tarihi itibariyle toplam iki milyondan fazla vaka olduğu, 28 binden fazla hastanın ise koronavirüs nedeniyle hayatını kaybettiği rapor edilmiştir (Sağlık Bakanlığı, 2021). Hem dünyada hem de Türkiye'de koronavirüs vaka sayılarındaki artış halen devam etmektedir.

Sağlık, ekonomi, toplum, ulusal ve küresel iletişimin güvenliği üzerinde yarattığ1 olumsuz etkiler nedeniyle pandemi bir kriz durumu olarak değerlendirilmekte (Qiu, Rutherford Mao ve Chu, 2016/2017) ve pandemi dönemlerinde, hastalığın bulaşma sürecini yönetmek için risk iletişimi (yetkili kişi ve kurumlar tarafindan topluma, sağlığ korumaya yönelik doğru bilgilerin verilmesi), aşılar ve anti-viral ilaçlar (hastalığın bulaşmasını önlemeye ve hastalığı tedavi etmeye yönelik tıbbi uygulamalar), hijyen uygulamaları (kişisel temizliğe dikkat edilmesi, maske ve dezenfektan kullanımı, ellerin sık sık yıkanması gibi) ve sosyal izolasyon (kalabalık ortamlardan uzak durulması, hasta olan ya da hasta olduğundan şüphe duyulan kişilerin karantinaya alınması gibi) gibi çeşitli yöntemler kullanılmaktadır (Taylor, 2019). Türkiye'de de ilk koronavirüs vakasının tespit edilmesinden sonra hastalığın yayılmasını önlemek amacıyla okulların, spor merkezlerinin, kafe ve restoranların kapatılması, yurt içi ve yurt dışı uçuşların yasaklanmaS1, şehirlerarası yolculuklara sınırlandırma getirilmesi, otobüslerdeki yolcu sayılarının sınırlandırılması, yurt dışından gelenlerin karantina altına alınması gibi çok çeşitli önlemler alınmıştır (T.C. İçişleri Bakanlığı, 2020a, 2020b, 2020c). Aynı zamanda kitle iletişim araçları aracılığıyla insanlara evde kalmaları, sık sık ellerini yıkamaları, sosyal 
mesafeyi korumaları ve gerekli durumlarda eldiven ve maske kullanmaları yönünde mesajlar verilmiştir.

Pandemi dönemlerinde her ne kadar toplu önlemler alınsa da hastalığın bulaşmasının önlenmesindeki en önemli faktör, kişilerin pandemiye karşı gösterdikleri bireysel tepkilerdir. Bu bireysel tepkiler önleyici davranışlar (el yıkamak, maske kullanmak ve aşı yaptırmak gibi), kaçınmaya yönelik davranışlar (kalabalıklardan ya da toplu ulaşımdan uzak durmak gibi) ve hastalık davranışlarının yönetimi (antiviral ilaçları kullanmak ya da profesyonellerden yardım istemek gibi) olmak üzere üç grupta incelenebilir (Bish ve Michie, 2010, s.798). Kişilerin pandemi karşısında gösterdikleri bu bireysel tepkilerin altında çok çeşitli psikolojik faktörler yatmakta ve pandemi dönemlerinde hastalığın bulaşmasını önlemek amacıyla kullanılan yöntemlerin başarısında da bu psikolojik faktörler önemli rol oynamaktadır (Taylor, 2019). Dolayısıyla koronavirüs halen dünya çapında yayılan bir sağlık problemi iken, insanların hastalığın bulaşmasını önlemek için gösterdikleri davranışları etkileyen psikolojik faktörleri araştırmak da önemlidir (Bish ve Michie, 2010; Oosterhoff ve Palmer, 2020). İnsanların pandemiyle ilgili tutum ve davranışlarını anlamak, hastalığı kontrol altına almak ve önleyici tedbirleri geliştirmek açısından yararlı olacaktır (Karademas, Bati, Karkania, Georgiou ve Sofokleous, 2013; Wise, Zbozinek, Michelini, Hagan ve Mobbs, 2020). İnsanların pandemi ile mücadelelerine yönelik tutum ve davranışları üzerinde etkili olan bu psikolojik faktörlere örnek olarak hastalığa yakalanma risk algısı, hastalığın ciddiyetine yönelik alg1, koruyucu davranışları uygulamaya yönelik algılanan yeterlik ve anksiyete verilebilir (Bish ve Michie, 2010; Rubaltelli, Tedaldi, Orabona ve Scrimin, 2020; Rubin, Amlôt, Page ve Wessely, 2009; Wang ve ark., 2020; Wheaton, Abramowitz, Berman, Fabricant ve Olatunji, 2012; Vally, 2020). Bunların içerisinde en çok üzerinde durulanlardan biri pandemiyle ilgili yaşanan anksiyetedir.

Koronavirüs pandemisi halen dünyada etkisini sürdürürken toplumların bu süreçte yaşadığı anksiyete düzeyinin ölçülmesi, hem hastalığın yayılma sürecini kontrol etme hem de ruh sağlığını korumaya yönelik stratejilerin ve müdahalelerin geliştirilmesi açısından önemlidir. Pandemiyle ilgili yaşanan anksiyete düzeyinin belirlenmesi halk sağlığ1 açısından önleyici tedbirlerin geliştirilmesi ve bireylerin ihtiyaç duydukları psikolojik desteğin sağlanması açısından yararlı olabilir. Bu noktada, bireylerin pandemiyle ilgili yaşadığı anksiyeteyi değerlendirmeye yönelik ölçme araçlarına ihtiyaç duyulmaktadır. Ulusal alan yazın incelendiğinde bireylerin koronavirüs nedeniyle yaşadığ 1 
korku, endişe ya da anksiyeteyi değerlendirmeye yönelik çeşitli ölçme araçlarının var olduğu görülmektedir. Bunlardan biri yurt dışında geliştirilen (Ahorsu ve ark., 2020) ve Türkçeye uyarlaması yapılan (Bakioğlu, Korkmaz ve Ercan, 2020; Haktanir, Seki ve Dilmaç, 2020) COVID-19 Korkusu Ölçeği'dir. Bu ölçek, bireylerin COVID-19 nedeniyle yaşadığı korkuyu terleme, endişe, uyku problemleri ve kalp çarpıntısı gibi semptomlar açısından değerlendirmektedir. Lee (2020) tarafından geliştirilen ve Türkçeye uyarlaması yapılan (Biçer, Çakmak, Demir ve Kurt, 2020; Evren, Evren, Dalbudak, Topcu ve Kutlu, 2020) bir diğer ölçme aracı olan Koronavirüs Anksiyete Ölçeği, COVID-19 kriziyle ilişkili olası disfonksiyonel anksiyete vakalarını tanılamayı amaçlamakta ve uykusuzluk, iştah bozulması, mide problemleri, baş ağrısı, donup kalma gibi semptomları değerlendirmektedir. Mevcut çalışmada ise Wheaton, Ward, Sanders, Reel ve van Meter (2020) tarafindan geliştirilen Koronavirüs Anksiyete Envanteri'nin (KAE) Türkçeye uyarlanması amaçlanmıştır. KAE, halihazırda var olan ölçme araçlarından farklı olarak koronavirüsle ilgili yaşanan anksiyeteyi değerlendirmek üzere bireylerin koronavirüsün yayılması, bulaşma olasıllı̆ı, hastalığın ciddiyeti, belirli yerler ve insanlardan kaçma, güvenlik davranışlarını uygulama ve virüs hakkında bilgiye maruz kalma düzeyleriyle ilgili endişelerine odaklanmaktadır (Wheaton ve ark., 2020).

\section{Pandemi Dönemlerinde Anksiyete}

Anksiyete, organizmanın tehlike karşısında ortaya koyduğu bir tepki (Geçtan, 1997), hoşa gitmeyen duygusal bir durum (Bhatia, 2009) ya da korkulu bir ruh hali (Matsumoto, 2009) olarak tanımlanmaktadır. Fiziksel sağlık için oluşturduğu tehdit nedeniyle pandemi dönemlerinde toplumlarda anksiyete düzeyi artış göstermektedir (Li, Wang, Xue, Zhao ve Zhu 2020). Etkililiği kesin olarak kanıtlanmış bir aşı ve tedavi yönteminin olmaması ve sürecin ne yöne gideceği konusunda yaşanan belirsizlikler nedeniyle koronavirüs pandemisi de toplumlarda anksiyetenin artışını tetiklemiştir (Duman, 2020). Koronavirüs pandemisi döneminde yapılan çalışmalar genel popülasyonda anksiyetenin yaygınlı̆̆ının Çin'de \%44.6 (Liu ve ark., 2020), Japonya'da \%33.2 (Ueda, Stickley, Sueki ve Matsubayashi, 2020), İtalya'da \%18.7 (Mazza ve ark., 2020), İspanya'da \%32.4 (Odriozola-González, Planchuelo-Gómez, Irurtia ve de Luis-García, 2020), İngiltere'de \%21.63 (Shevlin ve ark., 2020) ve Türkiye'de \%45.1 (Özdin ve Bayrak Özdin, 2020) düzeyinde olduğunu göstermektedir. Çin, İspanya, İtalya, İngiltere, Japonya, İran, Irak, Nijerya, Nepal ve Hindistan gibi farklı uluslarla gerçekleştirilen çaış̧maların sonuçlarını bir araya getirerek Salari ve arkadaşları (2020) tarafından yapılan 
bir meta-analiz çalışmasında ise koronavirüs pandemi döneminde genel popülasyonda anksiyetenin yaygınlığının \%31.9 olduğu bildirilmektedir.

Pandemi karşısında hissedilen anksiyete belirli bir düzeye kadar kişiyi koruyucu davranışlar sergilemeye motive etmekte, ancak yüksek düzeyde olduğunda klinik bir boyuta ulaşarak kişinin işlevselliğini bozabilmektedir (Taylor, 2019; Wheaton, ve ark., 2012). Öyle ki pandemi dönemlerinde yaşanan yüksek düzeydeki anksiyete hipkondria, agorafobi, obsesif kompulsif, bipolar bozukluk, panik bozukluk ve genelleştirilmiş anksiyete bozukluğu gibi psikolojik bozukların gelişimini tetikleyebilmektedir (Asıc1, 2020). Koronavirüs pandemisi sürecinde de toplumda anksiyete bozukluklarının arttığ1na ilişkin bulgular vardır (Huang ve Zhao, 2020). Diğer taraftan kişinin hiç anksiyete duymaması da hastalığın yayılması açısından büyük risk oluşturmaktadır. Să̆lık inanç modeline göre, bireyin sağlığı koruyucu davranışları, sahip olduğu inanç, değer ve tutumlardan etkilenmektedir. İnsanlar bir sağlık sorununun kendilerine zarar vermeyeceğine ya da hastalığın sonuçlarının ciddi olmadığına ilişkin inançlara sahip olduklarında sağlı̆̆ı koruyucu davranışları sergilemeye motive olmamaktadır (Hochbaum,1958; Janz, Champion ve Strecher, 2002; Rosenstock, 1960). Bu bağlamda pandemi dönemlerinde önleyici davranışların sergilenmesinde kişinin kendisini ne kadar risk altında gördüğü önemli bir rol oynamakta; ancak pek çok insan iyimser bir önyarg1 ile hasta olma riskinin diğer insanlara göre daha düşük olduğuna inanmakta (Wise ve ark., 2020), dolayısıyla anksiyete yaşamamaktadır. Sonuç olarak, kişinin yaşadığı anksiyetenin yüksek düzeyde olması pandemi bitse bile etkisi sürecek olan psikolojik sorunların gelişimini tetiklerken; anksiyetenin yokluğu ise toplumsal açıdan pandemiyle mücadele sürecini olumsuz etkilemektedir (Taylor, 2019).

Dünya genelinde pandemi ile mücadele sürecinin nasıl devam edeceği veya takip eden dalgaların olup olmayacağı konusundaki belirsizlikler varlığını sürdürmektedir. $\mathrm{Bu}$ da toplumun genelinde koronavirüs nedeniyle yaşanan anksiyetenin bir süre daha devam edeceğine işaret etmektedir. Bu nedenle, gerek koronavirüsle mücadele sürecine yön verebilmek gerekse de pandemi sonrasında ortaya çıkabilecek psikolojik sorunları önleyebilmek açısından, koronavirüs nedeniyle yaşanan anksiyetenin incelenmesi değerlidir. Koronavirüs pandemisinden en çok etkilenen gruplardan biri olması (Fernandes, 2021) sebebiyle, özellikle de üniversite öğrencilerinin yaşadığ 1 anksiyetenin değerlendirilmesi önem arz etmektedir. 
Türkiye' de koronavirüs vakalarının görülmeye başlanmasıyla birlikte, diğer ülkelerde olduğu gibi, virüsün yayılmasını önlemek amacıyla alınan ilk tedbirlerden biri üniversitelerin kapatılması olmuştur. Öncelikle üniversitelerin eğitimine üç hafta ara verilmiş (YÖK, 2020a), sonrasında da 2019-2020 eğitim öğretim yılının uzaktan eğitimle tamamlanması kararı alınmıştır (YÖK, 2020b). Üniversitelerin aniden kapatılmas1, pek çok üniversite öğrencisinin ailelerinin yanına dönmelerini gerekli kılmıştır; bu durumda sosyal ortamlarından uzaklaşarak arkadaşlarıyla gerçekleştirmeyi planladıkları etkinlikleri iptal etmek zorunda kalmış olmaları olasıdır. Sokağa çıkma yasakları ve evde kal uygulamaları nedeniyle diğer aktivitelere yönelemedikleri için pek çok öğrenci televizyon ya da sosyal medya aracılığıyla sürekli olarak koronavirüs ile ilgili haberlere maruz kalmış olabilir. Normal koşullarda ev içi emek harcayan kadınların ya da işsiz olduğu için çalışamayan bireylerin evde vakit geçirmeye alışık olmaları olası iken; üniversite öğrencileri için pandemi sürecinde evde olmak yeni bir yaşam düzeni demektir. $\mathrm{Bu}$ nedenle, koronavirüsle ilgili haberlere maruz kalmak üniversite öğrencilerinde ekstra olumsuz bir yük yaratmış olabilir. Nitekim, koronavirüs pandemisi sürecinde üniversite öğrencileriyle yapılan çalışmalar öğrencilerin koronavirüs pandemisiyle ilgili en çok korku, endişe ve kaygı gibi olumsuz duyguları yaşadıklarını (Asıcı ve Günlü, baskıda), gerek pandemi sürecinin gerekse de eğitim yaşamıyla ilgili belirsizliklerin yaşadıkları endişe ve kaygıyı arttıran önemli faktörler olduğunu (Ceviz, Tektaş, Basmacı ve Tektaş, 2020) göstermiştir. Ayrıca, uzaktan eğitim sürecine adapte olmakla ilgili yaşanan zorlukların (Özer, 2020; Yamamoto ve Altun, 2020) bir sonucu olarak öğrenciler, okula ve ders çalışmaya yönelik ilgilerini kaybetmişlerdir (Güngör, Karaman, Sari ve Çolak, 2020). Özetle, koronavirüs pandemisi ile birlikte kişisel, sosyal ve eğitim yaşamları hızla değişen öğrencilerin koronavirüs nedeniyle anksiyete yaşamaları mümkündür. Pandemi sürecinin ve risklerin tamamen ortadan kalkmamış olmasından, koronavirüs ile mücadelenin halen devam etmesinden ve eğitim öğretim sürecinde yaşanan belirsizlikten dolayı üniversite öğrencilerinin koronavirüs ile ilgili yaşadıkları anksiyetenin yoğun olabileceği düşünülebilir. Pandemi dönemlerinde yaşanan anksiyetenin koruyucu davranışların uygulanması ve bireyin ruh sağlığı üzerindeki etkisi dikkate alındığında üniversite öğrencilerinin koronavirüsle ilgili yaşadıkları anksiyetenin belirlenmesinin önemli olduğuna inanılmaktadır. Bu doğrultuda mevcut araştırmada, üniversite öğrencilerinin koronavirüs nedeniyle yaşadığı anksiyeteyi değerlendirmeye yönelik olarak KAE’nin (Wheaton ve ark., 2020) Türkçeye uyarlanması amaçlanmıştır. 


\section{YÖNTEM}

\section{Katılımcilar}

$\mathrm{Bu}$ çalışma için pilot uygulama ve nihai uygulama kapsamında iki kez veri toplanmıştır. Pilot uygulamaya 350 lisans öğrencisi, nihai uygulamaya ise 428 lisans öğrencisi katılmıştır. Pilot uygulamaya Türkiye’nin yedi farklı coğrafi bölgesinde, 13 farklı şehirdeki devlet üniversitelerinin Mimarlık-Mühendislik, İlahiyat, Eğitim ve Fen Edebiyat fakültelerinde öğrenim gören öğrenciler katılmıştır. Pilot uygulamaya katılan 350 öğrencinin 264'ü (\%75.4) kadın ve 86’s1 (\%24.6) erkektir. Öğrencilerin ikisi (\%0.6) birinci sınıf, 226’s1 (\%64.6) ikinci sınıf, 77'si (\%22) üçüncü sınıf ve 45’i (\%12.9) dördüncü sınıfta öğrenim görmektedir. Katılımcıların yaşları 18 ile 49 arasında değişmektedir $\left(\text { Ort }_{\text {yaş }}=22.50, S S=3.89\right)_{\text {. }}$

Nihai uygulamaya katılan ve Türkiye'nin yedi farklı coğrafi bölgesinde yaşayan 428 lisans öğrencisinin 335'i (\%78.3) kadın, 93’ü (\%21,7) erkektir. Öğrencilerin 60’1 (\%14) birinci sınıf, 160'1 $(\% 37,4)$ ikinci sınıf, 158'i $(\% 36,9)$ üçüncü sınıf ve 50’si $(\% 11,7)$ dördüncü sınıfta öğrenim görmektedir. Katılımcılar 19 farklı şehirden olup, yaşları 18 ile 32 arasında değişmektedir (Ort. yaș $=20.94, S S=1,74)$. Çalışmaya katılan öğrenciler Mimarlık-Mühendislik, İlahiyat, Eğitim ve Fen Edebiyat fakültelerinde öğrenim görmektedirler.

\section{Veri Toplama Araçları}

\section{Koronavirüs Anksiyete (Coronavirus Anxiety Inventory, CAI) Envanteri} (KAE). Uyarlaması yapılan ölçek ilk olarak Wheaton ve arkadaşları (2012) tarafından Domuz Gribi Anksiyete Envanteri (Swine Flu Inventory, SFI) olarak geliştirilmiştir. Dünyanın farklı bölgelerinde 2009 yılında görülen domuz gribi virüsü hayvanlardan insanlara bulaşmıştır. Domuz gribi ateş, öksürük, halsizlik ve baş ağrısı gibi belirtiler göstermekte, öksürme ve aksırma yoluyla insandan insana geçmektedir. Domuz gribinden korunmak için en çok önerilen yöntem, özellikle el yıkamak olmak üzere kişisel hijyene dikkat edilmesidir (TÜSAD, 2020). Hayvanlardan insanlara geçmiş olması, belirtileri, bulaşma yolları ve korunma yöntemleri açısından domuz gribi ile koronavirüs hastalığı arasında büyük benzerlikler vardır. Bu nedenle domuz gribi sürecinde yaşanan anksiyeteyi değerlendirmek amacıyla geliştirilen SFI'nın koronavirüs anksiyetesini değerlendirmede de kullanılabileceği düşünülmüş ve SFI, Wheaton ve arkadaşları (2020) tarafından KAE olarak uyarlanmıştır. KAE’nin geliştirilme sürecinde anksiyete bozuklukları ve somatizasyonu olan bireylerin değerlendirilmesi ve tedavisinde deneyimli bir grup klinisyen ve araştırmacı tarafından oluşturan 10 maddelik ölçek formu üniversite 
öğrencilerinden oluşan bir gruba uygulanmıştır. Toplanan verilerle yapılan madde analizi sonucunda 6. madde (How much exposure have you had to information about Coronavirus?/Koronavirüs hakkında ne kadar bilgi edindiniz?) dışındaki tüm maddelerin düzeltilmiş madde toplam korelasyonu değerinin .30'un üzerinde olduğu belirlenmiştir. Düzeltilmiş madde toplam korelasyonu değeri yetersiz olan 6 . madde çıkarılmış ve yapılan faktör analizi ve promax dik döndürme sonucunda tek faktörlü bir yapıya ulaşılmıştır. Ölçeğin Cronbach alfa iç tutarlılık katsayısı .88 olarak hesaplanmıştır. Ayrıca KAE ile beden uyanıklığı, bulaşma/kirlenme bilişleri, tiksinme, anksiyete ve stres, sağlık anksiyetesi ve anksiyete duyarlılı̆̆ fiziksel faktörü arasında pozitif yönde anlamlı ilişkiler olduğu tespit edilmiştir (Wheaton ark., 2012).

Orijinal KAE geliştirme çalışmasında 6. madde ölçekten çıkarılmış olmasına rağmen, farklı kültürlerde ve pandeminin farklı dönemlerinde yapılan çalışmalarda 6. maddenin yeterli uyum değerleri verebileceği düşünülerek mevcut araştırma 10 maddelik ölçek formu kullanılarak gerçekleştirilmiştir. 10 maddeden oluşan KAE, 5'li Likert cevaplama seçeneğine $(0=H i c ̧, 4=C ̧ o k$ fazla $)$ dayanmaktadır. KAE, bireylerin koronavirüsün yayılması, bulaşma olasıllı̆ı, hastalığın ciddiyeti, belirli yerler ve insanlardan kaçma, güvenlik davranışlarını uygulama ve virüsle ilgili bilgiye maruz kalma düzeyleriyle ilgili endişelerini değerlendirmeyi amaçlamaktadır. Envanterden alınan yüksek puanlar bireyin yaşadığı anksiyetenin yüksek olduğu anlamına gelmektedir (Wheaton ve ark., 2020).

Depresyon, Anksiyete, Stres Ölçeği (DASS-21). Depresyon, Anksiyete Stres Ölçeği (DASS) ilk olarak, Lovibond ve Lovibond (1995) tarafindan 42 madde ve 4'lü Likert tipine ( $0=$ Hiç bana uygun değil, $3=$ Bana tamamen uygun) dayalı olarak geliştirilmiştir. Antony, Bieling, Cox, Enns ve Swinson (1998) ise ölçeğin 21 maddelik kısa formunun geçerlik ve güvenirlik çalışmalarını gerçekleştirmiştir. Klinik ve klinik olmayan örneklemlerde bireylerin geçen hafta boyunca gösterdikleri olumsuz duygu durumunu değerlendirmeyi amaçlayan ölçek üç faktörden oluşmaktadır. Depresyon faktörü için örnek bir madde "Hiçbir beklentimin olmadığını hissetim.", anksiyete faktörü için örnek bir madde "Kendimi paniklemeye yakın hissettim." ve stres faktörü için örnek bir madde "Yaptığım şeyden beni alıkoyan hiçbir şeye tahammülüm yoktu." şeklindedir. Ölçekten toplam puan alınamamakta, her bir faktör için toplam puanlar ayrı ayrı hesaplanmaktadır. Alınan puanın artması, bireyin ilgili faktörün değerlendirdiği duygu durumunu daha çok yaşadığı anlamına gelmektedir. 
Ölçeğin 21 maddeden oluşan kısa formunun Türkçeye uyarlama çalışmaları Yıldırım, Boysan ve Kefeli (2018) tarafından gerçekleştirilmiştir. Türkçe form için yapılan geçerlik ve güvenirlik çalışmaları sonucunda, DASS-21'in olumsuz duygusal durumların sıklığını ve semptom şiddetini değerlendirmek için gereken psikometrik özelliklere sahip olduğu belirlenmiştir. DASS-21'in Türkçe formu için Cronbach alfa iç tutarlılık katsayıları depresyon için .89 , anksiyete için .87 ve stres için ise .90 olarak bulunmuştur. Mevcut çalışmada ise iç tutarlık katsayıları sırasıyla $.86, .84$ ve .87 olarak hesaplanmiştır.

Demografik Bilgi Formu. Araştırmaya katılan öğrencilerin, yaşı, cinsiyeti, kaçıncı sınıfta okudukları ve yaşadıkları şehre ilişkin bilgiler araştırmacılar tarafından oluşturulan bir demografik bilgi formu aracılığıyla toplanmıştır.

\section{İşlem}

Bu araştırma Düzce Üniversitesi Etik Kurul Başkanlı̆̆ı'ndan alınan etik kurul onayı çerçevesinde gerçekleştirilmiştir (Karar sayıs1: 2020/131). Ölçeğin Türkçeye çevirisi aşamasında öncelikle 26 Mart 2020 tarihinde orijinal çalışmanın yazarlarından e-posta yoluyla gerekli izin alınmış ve ölçek maddeleri mevcut çalışmanın yazarları tarafından İngilizceden Türkçeye çevrilmiştir. Sonrasında iki psikolojik danışmanlık ve rehberlik, bir ölçme ve değerlendirme, iki İngilizce dili ve bir halk sağlığı uzmanına, çevrilen maddeler ve İngilizce orijinal maddeler inceletilmiş, ölçeğin Türk diline uygunluğu konusunda uzmanların görüşleri alınmıştır. Uzmanların görüşleri doğrultusunda dört maddede biçimsel değişikliğe gidilmiş, gerekli düzenlemeler yapılmış ve ölçeğin son hali oluşturulmuştur. Alan yazında bazı durumlarda ölçek uyarlama çalışmalarında dilsel eş değerlik çalışmalarının tamamlanması için uzman görüşü alınmasının yeterli olabileceği belirtilmektedir (Seçer, 2015). Bu çalışmada da yaşanan pandemi nedeniyle sadece uzman görüşü alınması yeterli görülmüştür.

Türkçeye çeviri işlemlerinin tamamlanmasından sonra, 10 maddelik Türkçe ölçek formu orijinal çalışmada olduğu gibi lisans öğrencilerine uygulanarak 350 öğrenciden veri toplanmıştır. Çalışmaya katılan öğrenciler çalışmanın amacı ve çalışmaya katılmanın gönüllülük esasına dayandığı konusunda bilgilendirilmiştir. Çalışmanın verileri 2020 bahar döneminde, koronavirüs pandemisinden dolayı elektronik ortamda toplanmiştır.

Aşağıda ayrıntılı olarak sunulan sonuçlardan anlaşılacağı üzere pilot uygulamada toplanan veriler incelendiğinde istenilen düzeyde anlamlı istatistiksel değerler elde edi- 
lememiştir. Bu yüzden orijinal çalışmanın yazarından gerekli izin alındıktan sonra cevap seçenekleri 5'li yerine 7'li Likert ( $1=$ Hiç, $7=$ Çok fazla $)$ olarak yeniden oluşturulmuş ve altıncı madde için biçimsel değişikliğe gidilmiştir. Ölçeğin son hali ile ilk çalışmadan tamamen farklı bir örneklem kullanılarak 428 lisans öğrencisinden elektronik ortamda yeniden veri toplanmıştır. Veri toplama süreci 10 gün sürmüştür.

\section{Veri Analizi}

Araştırmanın amacı doğrultusunda, orijinal ölçek maddelerinin Türkçeye çevrilmesinin ardından, doğrulayıcı faktör analizi (DFA) gerçekleştirilmiştir. DFA sonucunda Türkçe ölçek formunun orijinal ölçek formundaki tek faktörlü yapısını koruyup korumadığı incelenmiştir. Ayrıca KAE ile depresyon, anksiyete ve stres arasındaki ilişkilerin incelenmesi yoluyla da yapı geçerliği kontrol edilmiştir. Önceki çalışmalar pandemi dönemlerinde bireylerin depresyon, anksiyete ve stres semptomlarının arttığını ve pandemiyle ilgili anksiyetenin depresyon, anksiyete ve stres semptomları ile ilişkili olduğunu ortaya koymaktadir (Goodwin, Haque, Neto ve Myers, 2009; Huang ve Zhao, 2020; Liu ve ark., 2020; Shevlin ve ark., 2020; Qian ve ark., 2020; Tan ve ark., 2020; Wang ve ark., 2020). Bu bağlamda KAE'deki puan artışlarının depresyon, anksiyete ve stresteki artış ile paralellik gösterip göstermediği incelenmiştir. Son olarak güvenirlik çalışmaları kapsamında Cronbach alfa iç tutarlılık katsayısı hesaplanmıştır.

Faktör analizi için MPlus (Muthén ve Muthén, 1998/2012), madde istatistikleri, Cronbach alfa ve korelasyonlar için R (R Development Core Team; 2009-2015) programı kullanılmıştır. DFA'da model uyum ölçütleri değerlendirilirken $\chi^{2} / \mathrm{sd} \leq 3$ (Kline, 2011), RMSEA $\leq .08$ (Browne ve Cudeck, 1993), TLI $\geq .95$, CFI $\geq .95$ (Bentler, 1980; Marsh, Hau, Artelt, Baumert ve Peschar, 2006) ve WRMR $<1$ (Yu, 2002) ölçütleri dikkate alınmıştır.

\section{BULGULAR}

\section{Pilot Uygulamaya İlişkin Bulgular}

Tablo 1'de pilot uygulamaya ilişkin madde ortalamaları, standart sapmalar, düzeltilmiş madde-toplam korelasyonu değerleri ile doğrulayıcı faktör analizine ilişkin faktör yükleri verilmiştir. Madde ortalamaları incelendiğinde ortalamaların oldukça yüksek olduğu görülmektedir. Veri seti incelendiğinde katılımcı cevaplarının genellikle son iki seçenekte yı̆̆ıldığ 1 görülmüştür. Bu yüzden maddelerin ve ölçeğe ilişkin toplam skorların varyansı ve standart sapması oldukça düşük çıkmıştır. Cronbach alfa değeri ise çok 
düşük bulunmuştur (.44). Benzer şekilde yapılan doğrulayıı faktör analizinde model uyum istatistikleri $\chi^{2} / s d=11.19, \mathrm{RMSEA}=.14, \mathrm{TLI}=.42, \mathrm{CFI}=.54, \mathrm{WRMR}=.93$ olarak bulunmuş olup ölçeğin tek faktörlü yapısı doğrulanamamıştır. Ayrıca maddelerin faktör yükleri incelendiğinde oldukça yetersiz sonuçlar verdiği saptanmıştır (Bkz. Tablo 1). Maddeler arasında altıncı maddenin faktör yükü ve düzeltilmiş madde toplam korelasyonu açısından en zayıf madde olduğu görülmüştür. Bu yüzden bu maddede biçimsel değişikliğe gidilmiştir.

Tablo 1. Pilot ve Nihai Uygulamaya İlişkin Madde Analizi İstatistikleri ve Faktör Yükleri

\begin{tabular}{|c|c|c|c|c|c|c|c|c|c|}
\hline \multirow[b]{2}{*}{ Madde } & \multicolumn{4}{|c|}{ Pilot Uygulamaya İlişkin Sonuçlar } & \multicolumn{5}{|c|}{ Nihai Uygulamaya İlişkin Sonuçlar } \\
\hline & Ort. & $S S$ & $\begin{array}{l}\text { Düzeltilmiş } \\
\text { madde- } \\
\text { toplam } \\
\text { korelasyonu }\end{array}$ & $\begin{array}{c}\text { Faktör } \\
\text { yükü }\end{array}$ & Ort. & $S S$ & $\begin{array}{c}\text { KAE-10 } \\
\text { Düzeltilmiş } \\
\text { madde- } \\
\text { toplam } \\
\text { korelasyonu }\end{array}$ & $\begin{array}{l}\text { KAE-9 } \\
\text { Düzeltilmiş } \\
\text { madde- } \\
\text { toplam } \\
\text { korelasyonu }\end{array}$ & $\begin{array}{c}\text { KAE-9 } \\
\text { Faktör } \\
\text { yükü }\end{array}$ \\
\hline$\overline{\mathrm{M} 1}$ & 3.54 & .96 & .38 & $.49^{*}$ & 5.22 & 1.33 & .66 & .68 & $.81^{*}$ \\
\hline M2 & 2.97 & .95 & .38 & $.48 *$ & 5.85 & 1.27 & .60 & .59 & $.70 *$ \\
\hline M3 & 3.10 & 1.02 & .46 & $.52 *$ & 4.19 & 1.43 & .55 & .57 & $.60 *$ \\
\hline M4 & 2.89 & .91 & .39 & $.49 *$ & 4.94 & 1.42 & .56 & .57 & $.59 *$ \\
\hline M5 & 3.21 & .64 & .51 & $.55^{*}$ & 5.62 & 1.26 & .56 & .56 & $.62 *$ \\
\hline M6 & 3.01 & .94 & .35 & $.24 *$ & 5.84 & 1.24 & .51 & .51 & $.62 *$ \\
\hline M7 & 2.78 & 1.06 & .40 & $.50^{*}$ & 5.12 & 1.61 & .49 & .51 & $.59 *$ \\
\hline M8 & 2.96 & 1.01 & .42 & $.51 *$ & 5.83 & 1.25 & .58 & .54 & $.66^{*}$ \\
\hline M9 & 3.11 & 1.25 & .43 & $.52 *$ & 6.06 & 1.62 & .35 & -- & -- \\
\hline M10 & 3.09 & 1.10 & .41 & $.49 *$ & 5.79 & 1.46 & .46 & .46 & $.56^{*}$ \\
\hline
\end{tabular}

${ }^{*} p<.01$ seviyesinde anlamlı, -- analizden çıkarıldığı için belirtilmemiştir.

\section{Nihai Uygulama İlişkin Madde ve Güvenirlik Analizi Sonuçları}

Ölçek maddelerine ilişkin madde ortalaması, standart sapma, düzeltilmiş madde-toplam korelasyonları Tablo 1'de verilmiştir. Ölçeğin 10 maddelik haline ilişkin madde ortalamalarının 6.06 (madde 9) ile 4.19 (madde 3) arasında, standart sapmalarının ise 1.62 (madde 9) ile 1.24 (madde 6) arasında değiştiği görülmektedir. Ölçeğin 10 maddelik haline ilişkin Cronbach alfa iç tutarlılık katsayısı değeri ise .82 olarak bulunmuştur. Düzeltilmiş madde-toplam korelasyonu değerleri incelendiğinde 10 maddelik formda dokuzuncu madde hariç tüm değerlerin Ebel ve Frisbie (1986) tarafından tavsiye edilen minimum .40 kriterinin üstünde olduğu görülmüştür. Bu yüzden dokuzuncu maddenin analizden çıkarılmasına karar verilmiştir. Geri kalan dokuz maddeyle ölçeğin geneline ilişkin toplam skorların ortalaması 48.44, standart sapması 8.19 olarak hesaplanmıştır. Ölçeğin dokuz maddelik haline ilişkin iç tutarlılık katsayısı olarak Cronbach alfa değeri ise .84 olarak bulunmuş olup dokuzuncu madde atıldığında iç tutarlık katsayısının arttığ1 görülmüştür. 


\section{Nihai Uygulama İlişkin Doğrulayıcı Faktör Analizi (DFA)}

Ölçeğin dokuz maddelik son halinin tek faktörlü yapısını test etmek için yapılan ilk DFA'dan elde edilen model-veri uyumu istatistiklerinde; $X^{2} / \mathrm{sd}=11.51$, $\mathrm{RMSEA}=.16$, $\mathrm{CFI}=.90, \mathrm{TLI}=.87$ ve $\mathrm{WRMR}=1.45$ olarak bulunmuştur. $\mathrm{Bu}$ değerler modelin yeterli uyum göstermediğini ve modifikasyon gerektirdiğini göstermektedir. Tavsiye edilen modifikasyon indeksleri doğrultusunda madde 2 ile madde 5 ve madde 3 ile madde 4'ün hata varyansları birbirine bağlanmış ve DFA yeniden yapılmıştır. Hata varyansları birbirine eşlenen maddeler incelendiğinde madde 2 ve 5 'in hastalığın yayılma hızına; madde 3 ve 4'ün ise hastalığın bulaşma olasılığına ilişkin algıyı değerlendirdiği görülmektedir. Maddeler arasındaki benzerlik dikkate alındığında yapılan modifikasyon uygun görülmektedir. Son analize ilişkin model-veri uyumu istatistikleri $X^{2} / \mathrm{sd}=2.90, \mathrm{RMSEA}=$ $.06, \mathrm{CFI}=.98, \mathrm{TLI}=.97, \mathrm{WRMR}=.55$ olarak bulunmuştur. $\mathrm{Bu}$ değerler ölçeğin tek faktörlü yapısının iyi uyum sağladığını göstermektedir. Tablo 1 'de verilen döndürülmüş madde yükleri incelendiğinde .81 (madde 1) ile .56 (madde 10) arasında değiştiği ve tüm madde faktör yüklerinin istatistiksel olarak anlamlı olduğu $(p<.01)$ görülmüştür. Hata varyansları birbirine bağlanan madde 2 ile madde 5 arasındaki korelasyon değeri $.24(p<.01)$, madde 3 ile madde 4 arasındaki korelasyon değeri $.33(p<.01)$ olarak bulunmuştur. Açıklanan varyans oranı incelendiğinde KAE'nin toplam varyansın .66 'sını (\%66) açıkladığı bulunmuştur.

KAE'nin yapı geçerliğini incelemek için, orijinal ölçek geliştirme çalışmasında olduğu gibi, KAE ile DASS-21 arasındaki korelasyonlara da bakılmıştır. DASS-21 ölçeğinin üç faktöründen elde edilen toplam skorlarına ilişkin betimleyici istatistikler, Cronbach alfa değerleri ve KAE ölçeğinden elde edilen toplam skorlar ile DASS-21'den elde edilen toplam puanlar arasındaki ikili korelasyon (zero-order) değerleri Tablo 2'de verilmiştir.

Tablo 2. Tanımlayıcı İstatistikler ve Değişkenler Arasındaki Korelasyonlar

\begin{tabular}{lcccccc}
\hline Değişken & Ort. & SS & KAE-9 & $\begin{array}{c}\text { DASS- } \\
\text { Depresyon }\end{array}$ & $\begin{array}{c}\text { DASS- } \\
\text { Anksiyete }\end{array}$ & DASS-Stres \\
\hline KAE-9 & 48.44 & 8.19 & $(.84)$ & $.34^{*}$ & $.38^{*}$ & $.45^{*}$ \\
DASS-Depresyon & 7.38 & 4.72 & & $(.86)$ & $.67^{*}$ & $.81^{*}$ \\
DASS-Anksiyete & 4.21 & 3.83 & & & $(.84)$ & $.74^{*}$ \\
DASS-Stres & 7.64 & 4.73 & & & & $(.87)$ \\
\hline
\end{tabular}

Not. ${ }^{*} p<.01$ seviyesinde anlaml, KAE-9= Koronavirüs Anksiyete Envanteri 9 maddelik form, DASS= Depresyon, Anksiyete, Stres Ölçeği 
Korelasyon analizi sonuçları (Bkz. Tablo 2) KAE'den alınan puanlar ile depresyon $(r(426)=.34, p<.01)$, anksiyete $(r(426)=.38, p<.01)$ ve stres $(r(426)=.45, p<.01)$ arasında istatistiksel olarak anlamlı düzeyde ve pozitif yönde ilişki olduğunu göstermiştir. KAE'nin stres ile en güçlü, depresyon ile en zayıf ilişkiyi gösterdiği görülmüştür. Ayrıca, ölçeğe ilişkin toplam puanlar için alt-üst \%27’lik gruplar arasında yapılan bağımsız örneklemler için $t$ testi sonuçlarına göre, alt-üst gruplar arasında anlamlı farklılık bulunmuştur $(t(228)=37.38, p<.001)$.

\section{TARTIŞMA}

$\mathrm{Bu}$ araştırmada, Wheaton ve arkadaşları (2020) tarafından geliştirilen KAE'nin Türkçeye çevrilmesi ve üniversite öğrencilerinde geçerlik ve güvenirliğinin incelenmesi amaçlanmıştır. Bu kapsamda pilot ve nihai olmak üzere iki ayrı çalışma yürütülmüş; madde analizi, güvenirlik ve yapı geçerliği analizleri gerçekleştirilmiştir.

KAE'nin 5'li Likert tipi cevaplama seçeneğine dayalı formu için gerçekleştirilen pilot çalışmanın sonuçları ölçeğin madde faktör yüklerinin yetersiz, düzeltilmiş madde toplam korelasyonu değerlerinin zayıf, Cronbach alfa iç tutarlık katsayısının çok düşük olduğunu ve tek faktörlü yapısının doğrulanmadığını göstermiştir. Bu sonucun, katılımcıların ölçek maddelerine verdikleri yanıtların son iki seçenekte yığılmasından ve bazı maddelerin anlaşılmamasından kaynaklandığı düşünülmüştür. Bunun üzerine bazı maddelerde biçimsel değişikliğe gidilerek cevap seçeneklerinin 5'li yerine 7'li Likert olarak oluşturulduğu nihai çalışma gerçekleştirilmiştir.

KAE'nin 7'li Likert tipi cevaplama seçeneğine dayal1 10 maddelik formu için yapılan madde analizi sonucunda dokuzuncu maddenin düzeltilmiş madde toplam korelasyonu değerinin alan yazında (Ebel ve Frisbie, 1986) önerilen .40 değerinin altında olduğu saptanmıştır. Bu nedenle dokuzuncu madde (Koronavirüs tehdidi seyahat planlarınızı ne kadar etkiledi?) ölçekten çıkarılmıştır. Koronavirüsün Türkiye'de başladığı ve tepe noktasına ulaştı̆̆ Mart-Nisan ayları üniversitelerde eğitim-öğretimin devam ettiği aylardır. Bu ayların tatil dönemine denk gelmiyor olması nedeniyle araştırmaya katılan öğrencilerin Mart-Nisan ayları için herhangi bir seyahat planlarının olmadığ1 düşünülebilir. Dolayısıyla dokuzuncu maddenin düzeltilmiş madde toplam korelasyonu değerinin düşük çıkması araştırmaya katılan öğrencilerin seyahat planlarının olmamasıyla ilgili olabilir. Diğer taraftan dokuzuncu maddenin düzeltilmiş madde toplam korelasyonu değerinin düşük çıkmasında koronavirüs nedeniyle uygulanan sokağa çıkma 
kısıtlamaları da etkili olmuş olabilir. Gelecekteki çalışmalar, dokuzuncu maddeye de yer vererek farklı zamanlarda ve örneklem gruplarında maddenin çalışıp çalışmadığını yeniden sinayabilirler.

Dokuzuncu maddenin ölçekten çıkarılmasından sonra elde kalan dokuz maddelik ölçek formu için Cronbach alfa iç tutarlık katsayısı .84 olarak bulunmuştur. Kayış’a (2014) göre, Cronbach alfa iç tutarlılık katsayısının .80'nin üzerinde olması ölçme aracının yüksek düzeyde güvenirliğe sahip olduğunu göstermektedir. Buna göre dokuz maddelik KAE’nin Türkçe formunun güvenilir bir ölçme aracı olduğu söylenebilir.

Nihai çalışma kapsamında dokuz maddelik ölçek formu için yapılan ilk DFA'dan elde edilen model-veri uyum istatistikleri yeterli düzeyde olmadığı için, modifikasyon önerileri doğrultusunda madde 2 ile 5 ve madde 3 ile 4'ün hata varyansları birbirine bağlanarak DFA yenilenmiştir. Yapılan son DFA sonuçları tek faktörlü ölçek yapısının model uyum indeksi değerlerinin iyi olduğunu göstermiştir (Bentler, 1980; Browne ve Cudeck, 1993; Kline, 2011; Marsh ve ark., 2006; Yu, 2002). KAE’nin Türkçe formuna ait faktör yük değerlerinin .56 ile .81 arasında değiştiği belirlenmişsir. Alan yazında madde faktör yükünün .32 ve üzerinde olması gerektiği vurgulanmaktadır (Tabachnick ve Fidell, 2013). Buna göre, KAE’nin Türkçe formu için elde edilen faktör yük değerlerinin yeterli düzeyde olduğu söylenebilir.

Ek olarak, orijinal ölçek geliştirme çalışmasında olduğu gibi KAE ile DASS-21 arasındaki korelasyonlara bakılmıştır. Sonuçlar KAE'den alınan puanlar arttıkça, depresyon, anksiyete ve stres puanlarında da istatistiksel olarak anlamlı düzeyde artış olduğunu göstermiştir. Pandemiyle ilgili anksiyetenin depresyon, anksiyete ve stres semptomları ile ilişkili olduğunu ortaya koyan geçmiş çalışmalarla (Goodwin ve ark., 2009; Huang ve Zhao, 2020; Liu ve ark., 2020; Shevlin ve ark., 2020; Qian ve ark., 2020; Tan ve ark., 2020; Wang ve ark., 2020) paralellik gösteren bu sonuçlar, orijinal çalışmada elde edilen değerlerle oldukça benzer olup KAE'nin yapı geçerliğine sahip olduğunun bir kanıtı şeklinde yorumlanmıştır. Pandemi karşısında hissedilen yüksek düzeydeki anksiyetenin bireyin işlevselliğini bozduğu (Taylor, 2019; Wheaton, ve ark., 2012) ve çeşitli psikolojik bozuklukların gelişimini tetiklediği (Asıcı, 2020) dikkate alındığında; pandemi nedeniyle anksiyete yaşayan öğrencilerde depresyon, anksiyete ve stres belirtilerinin artış gösterdiği söylenebilir. Diğer taraftan pandemi öncesinde depresyon, anksiyete ve stres düzeyi yüksek olan öğrencilerin pandemiyle ilgili daha çok anksiyete yaşıyor olmaları 
da olasıdır. Son olarak; alt-üst \%27'lik grupların ölçekten aldıkları puanlar karşılaştırıldığında alt-üst grupların puanları arasındaki farkın istatistiksel olarak anlamlı düzeyde olduğu görülmüştür. Buna göre, KAE’nin yüksek ve düşük puanları ayırt etme açısından yeterli olduğu söylenebilir (Can, 2014).

Bu çalışmada dokuz maddeden oluşan, 7'li Likert tipi cevaplama seçeneğine dayanan tek faktörlü KAE’nin Türkçe formunun üniversite öğrencileri örneklemi için geçerli ve güvenilir sonuçlar veren bir ölçme aracı olduğuna ilişkin bulgular elde edilmiştir. Yurt dışında pandemi karşısında insanların gösterdikleri tepkiler ve bu tepkilerin altında yatan psikolojik faktörlerle ilgili yapılmış olan çok sayıda çalışma (Bish ve Michie, 2010; Karademas ve ark., 2013; Moussaoui, Ofosu ve Desrichard, 2020; Oosterhoff ve Palmer, 2020; Pasion, Paiva, Fernandes ve Barbosa, 2020; Rubaltelli ve ark., 2020; Wang ve ark., 2020; Wise ve ark., 2020; Vally, 2020) olmasına rağmen yurt içinde bu tür çalışmalar daha sınırlıdır (örn., Ceviz ve ark., 2020; Kuru ve Uymaz, 2020). Bu nedenle araştırmacılara, KAE'yi kullanarak, üniversite öğrencilerinin yaşadıkları anksiyete ile pandemi karşısında gösterdikleri tepkiler arasındaki ilişkileri incelemeleri önerilebilir. Ayrıca KAE kullanılarak yüksek düzeyde anksiyete yaşayan ya da hiç anksiyete yaşamayan üniversite öğrencileri belirlenerek, onlara yönelik müdahale çalışmaları tasarlanabilir.

$\mathrm{Bu}$ araştırmanın bazı sınırlılıkları vardır. Araştırmanın ilk sınırlılığı, pandemi süreci nedeniyle dilsel eş değerlik çalışmasında sadece uzman görüşü alınmış olmasıdır. Araştırmanın ikinci sınırlılığı, araştırmanın orijinal ölçek geliştirme çalışmasında olduğu gibi üniversite öğrencilerinin katılımıyla gerçekleştirilmiş olmasıdır. Koronavirüsün her yaştan bireyi etkilediği dikkate alındığında, ölçeğin farklı yaş gruplarındaki psikometrik özelliklerinin değerlendirilmesi önerilmektedir. Özellikle toplumun diğer kesimlerine göre daha yüksek risk altında oldukları için ölçeğin sağlık çalışanları örnekleminde yapı geçerliğinin incelenmesi yararlı olabilir. Ayrıca bu çalışmaya sadece 19 farklı şehirden üniversite öğrencileri katılmış ve öğrencilerin pandemi süresince içinde bulundukları koşullar (örn., ekonomik güçlük yaşayıp yaşamadıkları, ailelerinden uzakta mı yoksa ailelerinin yanında mı üniversite eğitimi aldıkları, koronavirüs tanısı alıp almadıkları vb.) hakkında bilgi toplanmamıştır. Bu nedenle örneklemin Türkiye'deki tüm üniversite öğrencilerini temsil etmek açısından sınırlı olduğu göz önünde bulundurulmalıdır. Ek olarak araştırmaya katılan öğrencilerin \%70'inden fazlası kadındır. Gelecek çalışmalarda cinsiyete göre daha dengeli bir dağılımın sağlanması yararlı olabilir. Son olarak bu 
çalışma KAE’nin ölçüt bağıntılı geçerliğine ilişkin kanıtlar sunmadığından gelecek çalışmalarda ölçeğin ölçüt bağıntılı geçerliği test edilebilir.

Pandemi dönemlerinde yaşanan yüksek düzeydeki anksiyete pek çok ruh sağlığ1 probleminin gelişimini tetikleyebilir ya da hali hazırda bir ruh sağlığı problemi olan kişilerin durumunun daha da kötüye gitmesine yol açabilir. Bu nedenle, pandemi dönemlerinde her ne kadar öncelik hastalığı kontrol altına almak ve fiziksel sağlığ1 korumak olsa da pandeminin ruh sağlığı üzerindeki etkilerinin de dikkate alınması gerektiğine inanılmaktadır. Bu çalışmanın sonuçları KAE'nin Türk üniversite öğrencileri için geçerli ve güvenilir bir ölçme aracı olduğuna ilişkin çeşitli psikometrik bulguları ortaya koymaktadır. Pandeminin ortaya çıkaracağı ruhsal problemleri önleyebilmek açısından koronavirüs nedeniyle toplumda yaşanan anksiyetenin değerlendirilmesi ve koronavirüs anksiyetesi ile ilişkili faktörlerin incelenmesine yardımcı olması açısından ölçeğin alana katkı sağlaması beklenmektedir.

Hakem Değerlendirmesi: Dış bağımsız.

Yazar Katkıları: Çalışma Konsepti/Tasarım- E.A., H.İ.S., A.G.; Veri Toplama- E.A., H.İ.S., A.G.; Veri Analizi/ Yorumlama- E.A., H.İ.S., A.G.; Yazı Taslağı- E.A., H.İ.S., A.G.; İçeriğin Eleştirel İncelemesi- E.A., H.İ.S., A.G.; Son Onay ve Sorumluluk- E.A., H.İ.S., A.G.

Çıkar Çatışması: Yazarlar çıkar çatışması bildirmemiştir.

Finansal Destek: Yazarlar bu çalışma için finansal destek almadığını beyan etmiştir.

Peer-review: Externally peer-reviewed.

Author Contributions: Conception/Design of Study- E.A., H.İ.S., A.G.; Data Acquisition- E.A., H.İ.S., A.G.; Data Analysis/Interpretation- E.A., H.İ.S., A.G.; Drafting Manuscript- E.A., H.İ.S., A.G.; Critical Revision of ManuscriptE.A., H.İ.S., A.G.; Final Approval and Accountability- E.A., H.İ.S., A.G.

Conflict of Interest: The authors have no conflict of interest to declare.

Grant Support: The authors declared that this study has received no financial support.

\section{Kaynakça/References}

Ahorsu, D. K., Lin, C-Y., Imani, V., Saffari, M. Griffiths, M.D. ve Pakpour, A. H. (2020). The Fear of COVID-19 Scale: Development and initial validation. International Journal of Mental Health and Addiction (online first). https://doi.org/10.1007/s11469-0200270-8

Antony, M. M., Bieling, P. J., Cox, B. J., Enns, M. W. ve Swinson, R. P. (1998). Psychometric properties of the 42-item and 21-item versions of The Depression Anxiety Stress Scales in clinical groups and a community sample. Psychological Assessment,10(2), 176-181.

Asıcı, E. (2020). Salgının ruh sağlığı üzerindeki etkileri. TYB Akademi Dil Edebiyat ve Sosyal Bilimler Dergisi, 10(30), 123-142.

Asıc1, E. ve Günlü A. (baskıda). Üniversite öğrencilerinin gözünden COVID-19 salgını: Nitel bir araştırma. Gençlik Araştırmaları Dergisi, 9 (Salgın ve Gençlik Özel Sayısı), 5-23. 
Bakioğlu, F., Korkmaz, O. ve Ercan, H. (2020). Fear of COVID-19 and positivity. Mediating role of intolerance of uncertainity, depression, anxiety, and stress. International Journal of Mental Health and Addiction (online first). https://doi.org/10.1007/s11469-020-0033-y

Bentler, P. M. (1980). Multivariate Analysis with latent variables: Causal modeling. Annual Review of Psychology, 31, 419-456

Bhatia, M. S. (2009). Dictionary of psychology and allied sciences. New Delhi: New Age International Publisher.

Biçer, İ., Çakmak, C., Demir, H. ve Kurt, M. E. (2020). Koronavirüs Anksiyete Ölçeği Kısa Formu: Türkçe geçerlik ve güvenirlik çalışması. Anadolu Kliniği Tip Bilimleri Dergisi, 25(Özel sayı 1), 216-225. https://doi.org/10.21673/anadoluklin.731092

Bish, A. ve Michie, S. (2010). Demographic and attitudinal determinants of protective behaviours during a pandemic: A review. British Journal of Health Psychology, 15(4),797-824.

Browne, M. W. ve Cudeck, R. (1993). Alternative ways of assessing model fit. K.A. Bollen, ve J. S. Long (Ed.) Testing structural equation models içinde (s. 136-162). Beverly Hills.

Can, A. (2014). SPSS ile bilimsel araştırma sürecinde nicel veri analizi. Ankara: Pegem Akademi Yayıncilik

Ceviz, Ö. N., Tektaş, N., Basmacı, G. ve Tektaş, M. (2020). Covid 19 pandemi sürecinde üniversite öğrencilerinin kaygı düzeylerini etkileyen değişkenlerin analizi. Uluslararası Eğitim Araştırmacıları Dergisi, 3(2), 312-329.

Duman, N. (2020). Üniversite öğrencilerinde COVID-19 korkusu ve belirsizliğe tahammülsüzlük. The Journal of Social Science, 4(8), 426-437.

Ebel, R. L. ve Frisbie, D. A. (1986). Essentials of educational measurement. Englewood Cliffs: Prentice-Hall.

Evren, C., Evren, B., Dalbudak, E., Topcu, M. ve Kutlu, N. (2020). Measuring anxiety related to COVID-19: A Turkish validation study of the Coronavirus Anxiety Scale. Death Studies (online first). https://doi.org/10.1080/07481187.2020.1774969

Fernandes, A. J. (2021). Impact of COVID-19: University students' perspective. International Journal of Nutrition, Pharmacology, Neurological Diseases, 10, 168-169. https://doi.org/10.4103/ijnpnd. ijnpnd_60_20

Geçtan, E. (1997). Psikodinamik psikiyatri ve normaldışı davranışlar (13. Basım). İstanbul: Remzi Kitapevi.

Goodwin, R., Haque, S., Neto, F. ve Myers, L. B. (2009). Initial psychological responses to Influenza A, H1N1 ("Swine flu"). BMC Infectious Diseases, 9, 166. https://doi.org/10.1186/1471-2334-9-166

Güngör, A., Karaman, M. A., Sari, H. İ. ve Çolak, T. (2020). Investigating the factors related to coronavirus disease 2019 (COVID-19) on undergraduate students' interests in coursework. International Journal of Psychology and Educational Studies, 7(3), 1-13. https://doi.org/10.17220/ ijpes.2020.03.001

Haktanir, A., Seki, S. ve Dilmaç, B. (2020). Adaptation and evaluation of Turkish version of the Fear Of COVID-19 Scale. Death Studies (online first). https://doi.org/10.1080/07481187.2020.1773026

Hochbaum, G. M. (1958). Public paticipation in medical screening programs: A sociopsyhologicial study. PHS publication no: 572. Washington DC: Government Printing Office.

Huang, Y. ve Zhao, N. (2020). Generalized anxiety disorder, depressive symptoms and sleep quality during COVID-19 epidemic in China: A web-based cross-sectional survey. Psychiatry Research, 112954. https://doi.org/10.1016/j.psychres.2020.112954 
Janz, N. K., Champion,V. L. ve Strecher, V. J. (2002). The health belief model. K. Glanz, B. K. Rimer ve F. M. Lewis (Ed), Helath behavior and health education: 3rd Edition içinde (s. 45-66). San Fransisco: Jossey-Boss

Karademas, E. C., Bati, A., Karkania, V., Georgiou, V. ve Sofokleous, S. (2013). The association between pandemic influenza A (H1N1) public perceptions and reactions: A prospective study. Journal of Health Psychology, 18(3), 419-428.

Kayış, A. (2014). Güvenirlik analizi. Şerif Kalaycı (Ed.) SPSS uygulamalı çok değişkenli istatistik teknikleri içinde (s. 403-424). Ankara: Asil Yayın Dağıtım.

Kline, R. B. (2011). Principles and practice of structural equation modeling. New York: The Guilford Press.

Kuru, T. ve Uymaz, P. (2020). Anxiety, protective behaviors and related factors during the COVID-19 outbreak: A cross-sectional study. Acta Medica Alanya, 4(2), 186-192. https://doi.org/10.30565/ medalanya. 718083

Lee, S.A. (2020). Coronavirus anxiety scale: A brief mental health screener for COVID-19 related anxiety. Death Studies, 44(7), 393-401. https://doi.org/10.1080/07481187

Li, S., Wang, Y., Xue, J., Zhao, N. ve Zhu, T. (2020). The impact of COVID-19 epidemic declaration on psychological consequences: A study on active Weibo users. International Journal of Environmental Research and Public Health, 17(6), 2032. https://doi.org/10.3390/ijerph17062032

Liu, D., Ren, Y., Yan, F., Li, Y., Xu, X., Yu, X., ... ve Tan, S. (2020). Psychological Impact and Predisposing Factors of the Coronavirus Disease 2019 (COVID-19) Pandemic on General Public in China. Retrieved from https://papers.ssrn.com/sol3/papers.cfm?abstract_id=3551415

Lovibond, P. F. ve Lovibond, S. H. (1995). The structure of negative emotional states: Comparison of the depression anxiety stress scales (DASS) with the beck depression and anxiety inventories. Behaviour Research and Therapy, 33(3), 335-343.

Marsh, H. W., Hau, K. T., Artelt, C., Baumert, J. ve Peschar, J. L. (2006). OECD's brief self-report measure of educational psychology's most useful affective constructs: Cross-cultural, psychometric comparisons across 25 countries. International Journal of Testing, 6(4), 311-360.

Matsumoto, D. (2009). The Cambridge dictionary of psychology. New York: Cambridge University Press.

Mazza, C., Ricci, E., Biondi, S., Colasanti, M., Ferracuti, S., Napoli, C. ve Roma, P. A (2020). Nationwide survey of psychological distress among Italian people during the COVID-19 pandemic: Immediate psychological responses and associated factors. International Journal of Environmental Research and Public Health, 17(9), 3165. https://doi.org/10.3390/ijerph17093165

Moussaoui, L. S., Ofosu, N. D. ve Desrichard, O. (2020). Social psychological correlates of protective behaviours in the COVID-19 outbreak: Evidence and recommendations from a nationally representative sample. Applied Psychology: Health and Well-Being, 12(4), 1183-1204. https://doi. org/10.1111/aphw.12235

Muthén, L. K. ve Muthén, B. O. (1998/2012). Mplus user's guide. 7. bs. Los Angeles: Muthén \& Muthén.

Odriozola-González, P., Planchuelo-Gómez, Á., Irurtia, M. J. ve de Luis-García, R. (2020). Psychological symptoms of the outbreak of the COVID-19 confinement in Spain. Journal of Health Psychology, (online first). https://doi.org/10.1177/1359105320967086

Oosterhoff, B. ve Palmer, C. A. (2020). Psychological correlates of news monitoring, social distancing, disinfecting, and hoarding behaviors among US adolescents during the COVID-19 pandemic. PsyAeXiv (preprint version). https://doi.org/10.31234/osf.io/rpcy4 
Özdin, S. ve Bayrak Özdin, Ş. (2020). Levels and predictors of anxiety, depression and health anxiety during COVID-19 pandemic in Turkish society: The importance of gender. International Journal of Social Psychiatry, 66(5),504-511. https://doi.org/10.1177/0020764020927051

Özer, M. (2020). Educational policy actions by the ministry of national education in the times of COVID-19. Kastamonu Education Journal, 28(3), 1124-1129. https://doi.org/10.24106/ kefdergi.722280

Pasion, R., Paiva, T. O., Fernandes, C. ve Barbosa, F. (2020). The AGE effect on protective behaviors during the COVID-19 outbreak: Sociodemographic, perceptions and psychological accounts. Frontiers in Psychology, 11, 2785. https://doi.org/10.3389/fpsyg.2020.561785

Qian, M., Wu, Q., Wu, P., Hou, Z., Liang, Y., Cowling, B. J. ve Yu, H. (2020). Psychological responses, behavioral changes and public perceptions during the early phase of the COVID-19 outbreak in China: A population based cross-sectional survey. MedRxiv (yayın sürecinde). https://doi.org/10.1 101/2020.02.18.20024448

Qiu, W., Rutherford, S., Mao, A. ve Chu, C. (2016/2017). The Pandemic and its impacts. Health, Culture and Society, 9(10),1-11.

R Development Core Team. (2009-2015). R: A language and environment for statistical computing, reference index (Version 2.2.1). Vienna: R Foundation for Statistical Computing.

Rosenstock, I. M. (1960). What research in motivation suggests for public health. American Journal of Public Health, 50, 295-301.

Rubaltelli, E., Tedaldi, E., Orabona, N. ve Scrimin, S. (2020). Environmental and psychological variables influencing reactions to the COVID-19 outbreak. British Journal of Health Psychology, 25(4), 1020-1038. https://doi.org/10.1111/bjhp.12473

Rubin, G. J., Amlôt, R., Page, L. ve Wessely, S. (2009). Public perceptions, anxiety, and behaviour change in relation to the swine flu outbreak: Cross sectional telephone survey. Bmj, 339: b2651. https://doi.org/10.1136/bmj.b2651

Sağlık Bakanlığı (5 Mart 2021). Genel koronavirüs tablosu. Erişim adresi: https://covid19.saglik.gov. tr/TR-66935/genel-koronavirus-tablosu.html adresinden alınmıştır.

Salari, N., Hosseinian-Far, A., Jalali, R., Vaisi-Raygani, A., Rasoulpoor, S., Mohammadi, M., ... ve Khaledi-Paveh, B. (2020). Prevalence of stress, anxiety, depression among the general population during the COVID-19 pandemic: A systematic review and meta-analysis. Globalization and health, 16, 57. https://doi.org/10.1186/s12992-020-00589-w

Saunders-Hastings, P. R. ve Krewski, D. (2016). Reviewing the history of pandemic influenza: Understanding patterns of emergence and transmission. Pathogens, 5(4), 1-19.

Seçer, İ. (2015). Psikolojik test geliştirme ve uyarlama süreci: SPSS ve LISREL uygulamaları. Ankara: An1 yayıncilık.

Shevlin, M., McBride, O., Murphy, J., Miller, J. G., Hartman, T. K., Levita, L., ... ve Bentall, R. P. (2020). Anxiety, depression, traumatic stress, and COVID-19 related anxiety in the UK general population during the COVID-19 pandemic. Psyarxiv Preprints, 1-27.

Tabachnick, B. G. ve Fidell, L. S. (2013). Using multivariate statistics. 6. bs. Boston: Pearson.

Tan, B. Y., Chew, N. W., Lee, G. K., Jing, M., Goh, Y., Yeo, L. L., ... ve Sharma, V. K. (2020). Psychological impact of the COVID-19 pandemic on health care workers in Singapore. Annals of internal medicine, 173(4), 317-320. https://doi.org/10.7326/M20-1083

Taylor, S. (2019). The psychology of pandemics: Preparing for the next global outbreak of infectious disease. UK: Cambridge Scholars Publishing. 
T.C. İçişleri Bakanlığı (2020a, 28 Mart). Koronavirüs tebdirleri kapsamında şehirlerarası otobüs yolcu taşımacılığı ile ilgili ek genelge. Erişim adresi: https://www.icisleri.gov.tr/koronavirustebdirlerikapsaminda-sehirlerarasi-otobus-yolcu-tasimaciligi-ile-ilgili-ek-genelge.

T.C. İçişleri Bakanlığı (2020b, 21 Mart). Koronavirüs salgını ile mücadele kapsamında lokantalarla ilgili ek genelge. Erişim adresi: https://www.icisleri.gov.tr/koronavirus-salgini-ile-mucadelekapsamindalokantalarla-ilgili-ek-genelge.

T.C. İçişleri Bakanlığı (2020c, 21 Mart). Koronavirüs salgını ile mücadele kapsamında yeni kısıtlama ve tedbirler genelgeleri. Erişim adresi: https://www.icisleri.gov.tr/koronavirus-ile-mucadelekapsaminda-sokaga-cikma-kisitlamalari---yeni-kisitlama-ve-tedbirler-genelgeleri.

TÜSAD (2020, 1 Mayıs). Domuz gribi (Influenza H1N1) hakkında Türkiye Solunum Araştırmaları Derneği (TÜSAD) basın açıklamast. Erişim adresi: https://www.ttb.org.tr/h1n1/index. php?option=com_content\&view $=$ article \&id=117:turkiye-solunum-arastirmalari-dernegi-tusadbasin-aciklamasi- $\&$ catid $=55$ :kurumbasinaciklamalari\&Itemid $=140$

Ueda, M., Stickley, A., Sueki, H. ve Matsubayashi, T. (2020). Mental health status of the general population during the COVID-19 pandemic: A cross-sectional national survey in Japan. medRxiv. https://doi.org/10.1101/2020.04.28.20082453

Wang, C., Pan, R., Wan, X., Tan, Y., Xu, L., Ho, C. S. ve Ho, R. C. (2020). Immediate psychological responses and associated factors during the initial stage of the 2019 coronavirus disease (COVID-19) epidemic among the general population in China. International Journal of Environmental Research and Public Health, 17(5), 1729. https://doi.org/10.3390/ijerph17051729

Wheaton, M. G., Abramowitz, J. S., Berman, N. C., Fabricant, L. E. ve Olatunji, B. O. (2012). Psychological predictors of anxiety in response to the H1N1 (Swine Flu) pandemic. Cognitive Therapy and Research, 36(3), 210-218.

Wheaton, M. G., Ward, H. E., Sanders, P. R., Reel, J. E. ve Van Meter, A.R. (2020). Media effects on concerns about the spread of the novel coronavirus (COVID-19) in the United States. Manuscript Under Review.

World Health Organization (2021). WHO Coronavirus (COVID-19) dashboard. Erişim adresi: https:// covid19.who.int/ 5 March 2021.

Wise, T., Zbozinek, T. D., Michelini, G., Hagan, C. C. ve Mobbs, D. (2020). Changes in risk perception and protective behavior during the first week of the COVID-19 pandemic in the United States. PsyAeXiv (preprint version). https://doi.org/10.31234/osf.io/dz428

Vally, Z. (2020). Public perceptions, anxiety and the perceived efficacy of health-protective behaviours to mitigate the spread of the SARS-Cov-2/COVID-19 pandemic. Public Health, 187, 67-73. https:// doi.org/10.1016/j.puhe.2020.08.002

Yıldırım, A., Boysan, M. ve Kefeli, M. C. (2018). Psychometric properties of the Turkish version of the depression anxiety stress scale-21 (DASS-21). British Journal of Guidance ve Counselling, 46(5), $582-595$.

Yamamoto, G. T. ve Altun, D. (2020). Coronavirüs ve çevrimiçi (online) eğitimin önlenemeyen yükselişi. Üniversite Araştırmaları Dergisi, 3(1), 25-34. https://doi.org/10.32329/uad.711110

YÖK (2020a, 13 Mart). Koronavirüs (covid-19) bilgilendirme notu 1. Erişim adresi: https://www.yok. gov.tr/Sayfalar/Haberler/2020/coronavirus_bilgilendirme_1.aspx.

YÖK(2020b, 26 Mart). Basın açıklaması. Erişim adresi: https://www.yok.gov.tr/Sayfalar/Haberler/2020/ YKS\%20Ertelenmesi\%20Bas\%C4\%B1n\%20A\%C3\%A7\%C4\%B1klamas\%C4\%B1.aspx

Yu, C. Y. (2002). Evaluating cutoff criteria of model fit indices for latent variable models with binary and continuous outcomes. (Doktora Tezi). Los Angeles: University of California, 2002 


\section{EK-1}

\section{KORONAVIRÜS ANKSIYYETE ENVANTERİ}

Yönerge: Aşağıdaki her bir soruyu okuyunuz ve geçtiğimiz son iki haftayı düşünerek 1(Hiç) - 7(Çok fazla) arasında değişen yandaki derecelendirmeyi kullanarak soruyu yanıtlayınız.

1. Koronovirüs sizi ne kadar endișelendiriyor?

2. Koronavirüsün Türkiye'de bir "salgın” haline gelebileceğine ne kadar inaniyorsunuz?

3.Koronavirüsün size bulaşmasını ne kadar olası görüyorsunuz?

4.Koronavirüsün tanıdığınız birine bulaşmasını ne kadar olası görüyorsunuz?

5. Koronavirüsün Türkiye'de ne hızda yayıldığına inanıyorsunuz?

6. Koronavirüs hakkındaki bilgi ve haberleri ne kadar takip ediyorsunuz?

7. Koronavirüs size bulaşsaydı, ciddi bir şekilde hasta olacağınızdan ne kadar endişelenirdiniz?

8. Koronavirüs tehdidi insanların etrafında veya yakınında olma kararlarınızı ne kadar etkiledi?

9. Koronavirüs tehdidi seyahat planlarınızı ne kadar etkiledi?

10. Koronavirüs tehdidi kişisel hijyen davranışlarınızı (el dezenfektanı ya da kolonya kullanımı, sık sık el yıkama gibi) ne kadar etkiledi?

$\begin{array}{lllllll}1 & 2 & 3 & 4 & 5 & 6 & 7 \\ 1 & 2 & 3 & 4 & 5 & 6 & 7 \\ 1 & 2 & 3 & 4 & 5 & 6 & 7 \\ 1 & 2 & 3 & 4 & 5 & 6 & 7 \\ 1 & 2 & 3 & 4 & 5 & 6 & 7 \\ 1 & 2 & 3 & 4 & 5 & 6 & 7 \\ 1 & 2 & 3 & 4 & 5 & 6 & 7 \\ 1 & 2 & 3 & 4 & 5 & 6 & 7 \\ 1 & 2 & 3 & 4 & 5 & 6 & 7 \\ 1 & 2 & 3 & 4 & 5 & 6 & 7\end{array}$

Not: Ölçek kullanımı için yazarlardan izin alınmasına gerek yoktur. Bu çalışmayı uygun şekilde kaynak göstermek suretiyle ölçek kullanıma açıktır. 